\title{
Patrones de distribución vertical y horizontal de la epífita endémica Prosthechea aff. karwinskii (Orchidaceae) en Michoacán, México
}

\author{
Laura L. Cedillo ${ }^{1}$, Carlos Gómez-Alonso $^{2}$ \& Irene Ávila-Díaz ${ }^{1 *}$
}

${ }^{1}$ Facultad de Biología, Universidad Michoacana de San Nicolás de Hidalgo (UMSNH), Edif. R planta baja, Ciudad Universitaria, 58040 Morelia, Michoacán, México; ${ }^{2}$ Centro de Investigación Biomédica de Michoacán, IMSS, Camino de las Arboledas No. 300, Fracc. Exhda. San José de la Huerta, 58341 Morelia,

Michoacán, México;*Autor para correspondencia: iaviladiaz5@gmail.com

Prosthechea aff. karwinskii, orquídea epífita endémica de Michoacán, México, con solo una población conocida. El presente estudio tiene como objetivo determinar los patrones de distribución vertical y horizontal de $P$. aff. karwinskii de acuerdo a su estructura poblacional. Se censaron 355 orquídeas considerando: largo y ancho del pseudobulbo más joven bien desarrollado, número de eventos reproductivos, sección y zona del forofito, orientación, posición en la rama y sustrato. Los análisis estadísticos se realizaron a cada clase de vida (plántula, juvenil, adulta $1 \mathrm{y}$ adulta 2), contemplando un P-valor $<0.05$. Todas las clases de vida presentaron mayores frecuencias en la sección copa, en las zonas del forofito las plántulas se distribuyeron homogéneamente y las demás clases registraron mayores frecuencias en la parte media y parte interna de las ramas, las orientaciones Este, Sur y Oeste, resultaron las más frecuentes; en la posición en la rama las plántulas tuvieron mayor frecuencia en la parte lateral y en ramas verticales y las adultas 2 en la posición lateral y abajo; las plántulas presentaron la mayor frecuencia sobre sutrato de líquen, las juveniles sobre líquen y corteza y las adultas tuvieron mayor afinidad por la corteza. La distribución resultó más homogénea en las primeras clases de vida y con tendencia a ciertas variables conforme avanza el ciclo de vida, también se observó una diferencia entre los sitios donde la semilla germina y aquellos donde las plantas finalmente se establecen. Se observó que $P$. aff. karwinskii tiene como hospedero específico a Quercus desertícola.

\section{Horizontal and vertical distributional patterns of epiphytic Orchidaceae in a cloud forest in Colombia}

\author{
Marcela Cuartas-Domínguez ${ }^{1,2}$
}

\begin{abstract}
${ }^{1}$ Grupo de Investigación en Orquídeas, Ecología y Sistemática Vegetal. Universidad Nacional de Colombia, Sede Palmira, Colombia; ${ }^{2}$ Revista Acta Agronómica, Biblioteca (segundo piso), Universidad Nacional de Colombia, Carrera 32 No. 12-00, Palmira, Valle del Cauca, Colombia; marcelcd28@yahoo.es
\end{abstract}

Utilizing canopy ascent techniques in a cloud forest in the Western Cordillera of the Andes in Colombia, 25 trees with diameter at breast height $(\mathrm{DBH}) \geq 30 \mathrm{~cm}$ were climbed. In each tree, the location of epiphytic orchids was noted to determine location preferences in certain zones on the trees and whether the orchids prefer trees of a certain size distributed in three diameter categories: small trees (30-35 cm DBH), medium-sized $(35-50 \mathrm{~cm} \mathrm{DBH})$, and large $(\mathrm{DBH}>50 \mathrm{~cm})$. A total of
1,813 individuals of 44 species of orchids belonging to 14 genera was registered. Analysis of variance carried out for 23 species represented by more than five individuals and located in at least three trees revealed that 12 species showed a tendency to be located on trees of a certain size, in different elevational zones on trees, or both. Elleanthus sp.1, Maxillaria aurea, and Stelis sp.1 showed significant differences for both of these parameters. Two other analyses were carried out, one 
for total abundance and another for species richness, to determine if there were differences between different categories of diameter and different elevational zones within trees. Results showed greater abundance and richness of orchids in the canopy of the medium-sized trees. Thus, estimates of plant diversity in cloud forests including the canopy are important. With regard to size of trees, it could be argued that the three diameter categories are associated with different temporal stages in the population dynamics of these orchids.

\title{
Reproductive biology of Masdevallia coccinea and Masdevallia ignea in Guasca (Cundinamarca: Colombia)
}

\author{
Mónica Adriana Cuervo Martínez ${ }^{1 *}$, Rodrigo Bustos Singer ${ }^{2}$ \\ \& Maria Argenis Gómez Bonilla ${ }^{1}$
}

\begin{abstract}
${ }^{1}$ Grupo de Investigación Biología de Organismos Tropicales, Departamento de Biología Universidad Nacional de Colombia, Diagonal 82C- 73A- 59 interior 22 Conjunto Residencial Belmonte Priemra Etapa, Barrio Minuto de Dios, Bogotá, Colombia; ${ }^{2}$ Universidade Federal do Rio Grande do Sul

*Author for correspondence: macuervom@unal.edu.co
\end{abstract}

Masdevallia coccinea and Masdevallia ignea (popularly known as "banderitas") are ornamental orchids which are prized by amateur farmers and collectors. In Colombia, the harvest pressure on these species has been enormous, and few natural populations survive. Therefore, both species are on Appendix II of CITES. The goal of the project was to study the reproductive biology and pollination biology of M. coccinea and the M. ignea (Pleurothallidinae) under semi-cultivation conditions in the Villa Rosa farm located in the Municipality of Guasca, Cundinamarca (Colombia). For both species we studied floral morphology, phenology, breeding system, floral visitors, and pollinators, as well as visual and chemical cues. Masdevallia coccinea and M. ignea differ in floral color and in length of the sepals. In both species the labellum is articulated at the base of the column, but the lip is devoid of nectar and osmophores. Both species flower asynchronously and are self-compatible but pollinator-dependent. Masdevallia coccinea and $M$. ignea were visited by 15 and 7 insect morphospecies, respectively. Both orchid species were pollinated by female flies (Diptera: Drosophilidae) that performed different activities on the flowers. The flowers of $M$. coccinea and $M$. ignea reflected through all wavelengths such as UV, blue, and red. Floral volatiles of $M$. coccinea and $M$. ignea were also different.

\section{Identificación de bacterias endófitas asociadas a raíces de Cattleya quadricolor Lindl.}

\section{Luz Ángela Guerrero1, Jissel Pérez-Quiroga ${ }^{1}$, María Alejandra Quintero', Alberto Rojas-Triviño ${ }^{2 *} \&$ J. Tupac Otero ${ }^{2,3}$}

${ }^{1}$ Ingeniería Agronómica, Facultad de Ciencias Agropecuarias, Grupo de Investigación en Orquídeas, Ecología

y Sistemática Vegetal. Universidad Nacional de Colombia Sede Palmira, Colombia; ${ }^{2}$ Facultad de Ciencias

Agropecuarias, Grupo de Investigación en Orquídeas, Ecología y Sistemática Vegetal. Universidad Nacional de Colombia Sede Palmira, Colombia; ${ }^{3}$ Instituto de Estudios Ambientales IDEA- Palmira, Universidad Nacional de

Colombia sede Palmira, Colombia; *Autor para correspondencia: earojast@unal.edu.co

Las bacterias endófitas se encuentran colonizando los tejidos internos de las plantas sin ocasionar infección y aportando características competitivas importantes para éstas. El objetivo de este trabajo fue identificar especies endófitas asociadas a raíces de $C$. quadricolor. Los aislamientos se realizaron lavando las muestras con agua corriente, desinfectando con hipoclorito de sodio $1 \% / 3 \mathrm{~min}$, etanol $50 \% / 3 \min$ y agua destilada estéril; posteriormente, se retiró la corteza y se maceró el cilindro central, sembrando 